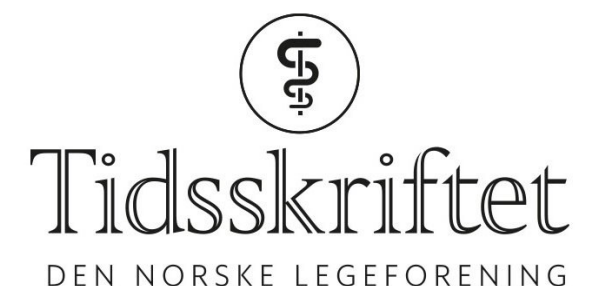

\title{
Hvordan er det å sitte og se på at jeg $\mathrm{d} \emptyset \mathrm{r}$ ?
}

PERSONLIGE OPPLEVELSER

CATHRINE NORDSTRAND

E-post: nordstrand.cathrine@gmail.com

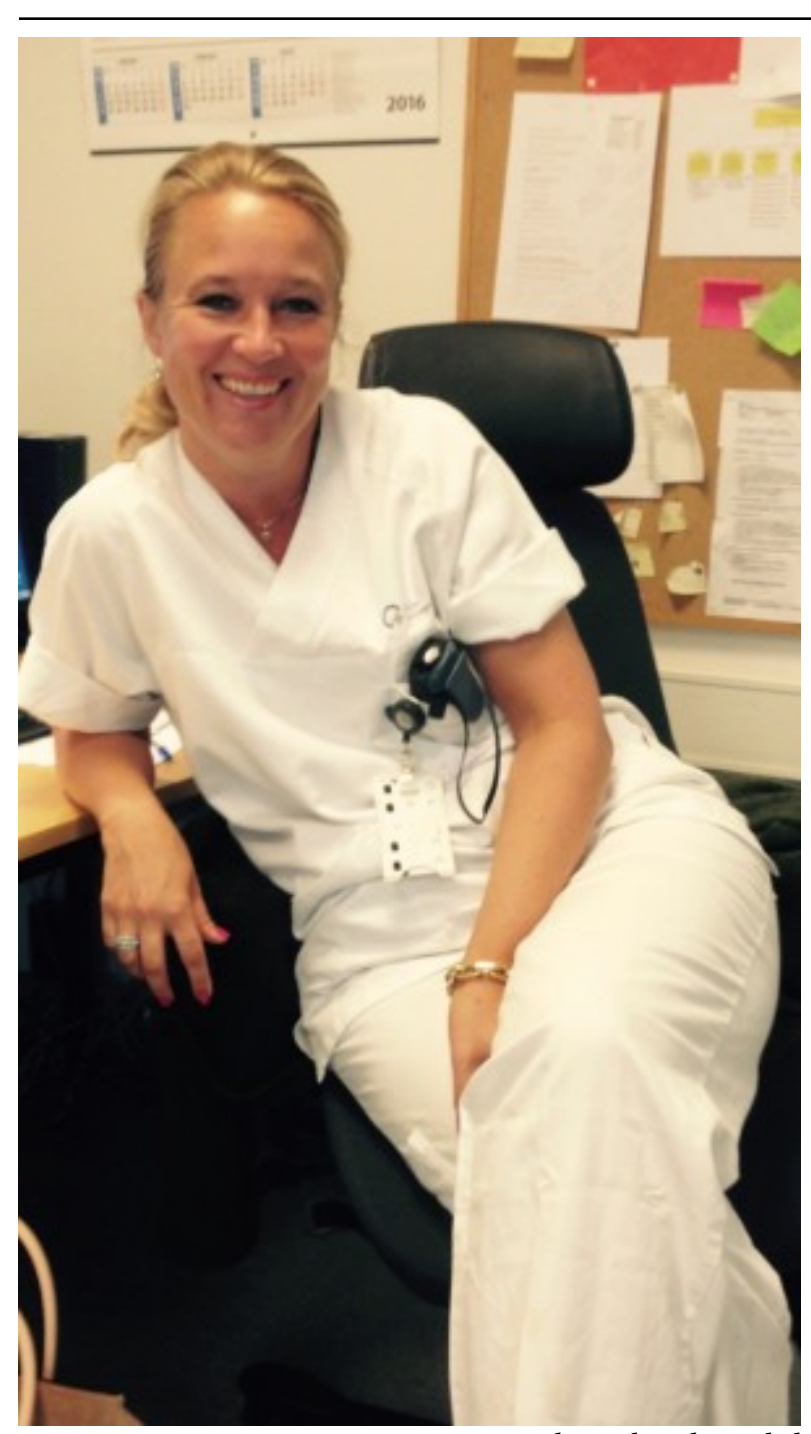

Det jeg savner mest som pasient med en alvorlig sykdom, er følelsen av at det er noen andre som kjemper for meg.

Jeg er i slutten av 40-årene og har en sønn i tenårene. Jeg fikk diagnosen amyotrofisk lateralsklerose (ALS) for knapt tre år siden. Før jeg ble syk, arbeidet jeg som sosionom. I de 
20 årene jeg jobbet med rus og psykiatri, var det viktig for meg å ha gode holdninger til de menneskene jeg var satt til å hjelpe. Jeg gjorde alt i min makt for å stå opp for pasientene mine og kan se tilbake på så mange fine øyeblikk, både med pasienter og pårørende. En rettesnor for meg i mitt arbeid var tanken på hvordan jeg selv hadde ønsket å bli behandlet hvis jeg ble lagt inn på avdelingen jeg jobbet på.

Så kom dagen da jeg fikk diagnosen. Det jeg husker best, er at nevrologen som ga meg beskjeden, ristet på hodet og sa at det ikke var noe å gjøre. Jeg, som hadde roet meg selv i ukene før diagnosen med å minne meg om at jeg bor i rike Norge, og at det meste kan fikses, ble møtt med avmakt. Ingen kunne hjelpe meg. Og noe av det såreste er kanskje dette: Jeg har opplevd det som om ingen av de helsearbeiderne jeg har møtt, har vist vilje til å prøve å stå opp for meg og prøve alt som tenkes kan for å se om noe kan hjelpe meg.

Det å møte opp på ALS-team hver tredje måned for at det skal journalføres at jeg blir stadig sykere, er svært lite tilfredsstillende for meg. Etter å ha skrevet tusenvis av journalnotater ville det vært en smal sak for meg å skrive mitt eget journalnotat og sende det inn. Det å snakke om hvordan livet har vært de siste tre måneder og hvordan jeg merker utviklingen av sykdommen, krever vel ingen spesialistkompetanse? For det er det som skjer i samtalene med ALS-teamet, i tillegg til at det blir tatt en spirometri.

Det å få et håp vil være til det beste for de fleste som har ALS. Jeg har sett frem til Høies ekspertpanel, som nylig er utnevnt (1). Det består av åtte kreftleger, hvorav syv er menn. Jeg hadde ønsket at en nevrolog (og eventuelt spesialister fra andre fagområder) var representert. Det ville styrket muligheten for at vi som er pasienter innen andre sykdomsgrupper enn kreft, også kan få tilgang til å prøve ut siste-håp-medikamenter.

Min erfaring er at mange andre alvorlig syke opplever det samme som meg. Vi må kjempe for å bli hørt, og vi får per i dag ingen behandling. Det er ikke godt nok.

\section{LITTERATUR:}

1. Bordvik M. Dette er ekspertene som skal gi dødssyke ny vurdering. Dagens Medisin 31.10.2018. https://www.dagensmedisin.no/artikler/2018/10/31/dette-er-ekspertene-som-skal-gi-dodssyke-ny-vurder ing/(7.11.2018).

Publisert: 14. januar 2019. Tidsskr Nor Legeforen. DOI: 10.4045/tidsskr.18.o636

(C) Tidsskrift for Den norske legeforening 2020. Lastet ned fra tidsskriftet.no 